\title{
KESIAPAN ORGANISASI TERHADAP KEY PERFORMANCE INDICATOR (KPI) DENGAN PERANCANGAN PERFORMANCE DASHBOARD
}

\section{Organizational Readiness on Key Performance Indicator (KPI) with Dashboard Performance Design}

\author{
M. Fauzi Isputrawan ${ }^{1)}$ \\ ${ }^{1)}$ Sistem Informasi/Fakultas Sistem Informasi, Universitas Bina Nusantara
}

Diterima 17 Mei 2018 / Disetujui 31 Juli 2018

\begin{abstract}
Improving the performance of a company is a factor that is highly considered in the face of increasingly fierce competition in the same industry. PT Kebayoran Pharma already understands this, but does not yet have a way to measure the performance of the business. Therefore, researchers want to discusses how to improve company performance by designing the Performance Dashboard and Key Performance Indicator (KPI) through the vision, mission and objectives of the company PT Kebayoran Pharma especially in Hospital \& Laboratory Division (Hoslab) so as to obtain KPIs for each employee in the Hoslab division using Balanced Scorecard unit method. In order to improve the performance of employees at the company and adds value (value-add) to consumers, each business unit need to revisit the strategy adopted in achieving the goals of the company. Not only from the size of operating excellence, but customer orientation, the company's contribution and future orientation is a factor to be considered in order to achieve long-term goals of company. This matter needs to be done due to various reasons such as the company's strategy that has been worn, the management does not work optimally or some other phenomena that could hinder the development of the company.

Keywords: Key Performance Indicator (KPI), Balanced Scorecard, Performance Dashboard.
\end{abstract}

\begin{abstract}
ABSTRAK
Peningkatan kinerja suatu perusahaan merupakan faktor yang sangat dipertimbangkan dalam menghadapi persaingan yang semakin ketat dalam industri yang sama. PT Kebayoran Pharma sudah mengerti hal tersebut, tetapi belum memiliki cara untuk mengukur kinerja dari usahanya itu tersebut. Oleh karena itu, peneliti ingin membahas bagaimana meningkatkan kinerja perusahaan dengan merancang Performance Dashboard dan Key Performance Indicator (KPI) dari Visi, Misi dan tujuan perusahaan PT Kebayoran Pharma sampai unit kerja Divisi Hospital \& Laboratory (Hoslab) sehingga memperoleh KPI untuk setiap karyawan di divisi Hoslab dengan menggunakan metode unit Balanced Scorecard. Dalam rangka meningkatkan kinerja karyawan pada perusahaan dan memberikan nilai tambah (value-add) kepada konsumen, setiap unit bisnis perlu meninjau kembali strategi yang diterapkan dalam mencapai sasaran perusahaan. Tidak hanya dilihat dari ukuran keunggulan operasi saja, tetapi orientasi pelanggan, kontribusi perusahaan dan orientasi kedepan merupakan faktor yang perlu dipertimbangkan dalam rangka mencapai tujuan jangka panjang perusahaan.Hal ini perlu untuk dilakukan dikarenakan berbagai alasan seperti salah satu tahap strategi perusahaan yang telah usang, unit manajemen yang tidak bekerja dengan optimal atau beberapa fenomena lain yang dapat menghambat perkembangan perusahaan.
\end{abstract}

Kata Kunci: Key Performance Indicator (KPI), Balanced Scorecard, Performance Dashboard.

\section{PENDAHULUAN}

Peningkatan kinerja suatu perusahaan merupakan faktor yang sangat dipertimbangkan dalam menghadapi persaingan yang semakin ketat dalam industri yang sama. Hal ini menuntut setiap perusahaan untuk dapat melaksanakan 
strateginya dalam memenangkan persaingan dan mampu menggunakan sumber daya manusianya secara lebih efektif dan efisien sehingga visi perusahaan dapat tercapai. Dengan demikian, perusahaan akan terus berupaya untuk merumuskan dan menyempurnakan strategi-strategi bisnis mereka dalam rangka memenangkan persaingan. Kemampuan perusahaan dalam menetapkan keputusan dan kebijakan strateginya akan sangat menentukan kelangsungan hidup perusahaan dalam jangka panjang.

Pengelolaan kinerja pegawai secara efektif merupakan salah satu faktor kunci untuk meningkatkan kinerja bisnis perusahaan. Dalam hal ini, pengelolaan kinerja yang efektif mencakup proses pengukuran hasil kerja karyawan secara obyektif melalui serangkaian indikator kinerja yang tepat. Melalui metode pemilihan Key Performance Indicator (KPI), diharapkan proses pembinaan kinerja pegawai dapat dilakukan dengan optimal, obyektif dan memberikan kontribusi positif bagi kinerja bisnis perusahaan.

Oleh karena itu peneliti akan merancang suatu sistem pengukuran kinerja (Key Performance Indicator) dan Performance Dashboard yang efektif dan efisien dengan metode unit Balanced Scorecard dalam suatu perusahaan PT Kebayoran Pharma khususnya Divisi Hoslab. Dengan demikian dapat diketahui objektif, Key Performance Indicator (KPI) untuk setiap karyawan dan action plan yang akan dilakukan.

Setelah melakukan peninjauan langsung ke perusahaan PT. Kebayoran Pharma (PTKP) dan melakukan interview langsung dengan pihak perusahaan mengenai permasalahan yang dialami perusahaan khususnya dalam divisi Hospital \& Laboratory (Hoslab) maka kami mendapatkan beberapa masalah, yaitu:

Pertama, PTKP belum memiliki sistem pengukuran kinerja dan indikator keberhasilan (key performance indicator) yang cukup objektif. Hal ini menyebabkan perusahaan sulit melakukan pengukuran tingkat keberhasilan atas kinerja perusahaan secara keseluruhan maupun unit kerja tertentu dalam perusahaan tersebut.

Kedua, PTKP memiliki kendala dalam mengkomunikasikan rencanarencana strategis bisnis dari top level manajemen kepada para pelaksananya di lapangan, yaitu karyawan. Sehingga menyebabkan masing-masing karyawan bekerja tanpa strategi yang jelas

*Korespondensi Penulis:

E-mail: mfauziis@gmail.com

\section{STUDI PUSTAKA}

\section{Performance Dashboard}

Pada dasarnya performance dashboard adalah suatu laporan yang efektif yang dirancang dengan mengembangkan sebuah laporan yang menampilkan semua KPI penting dalam format presentasi visual, dalam bentuk grafik, diagram dan tabel (Alexander, 2007). Laporan dashboard harus tersusun simpel dan mudah dipahami oleh manajer maupun para karyawan. Dashboard menyampaikan informasi mengenai aspekaspek utama dari perusahaan untuk mengetahui posisi kinerja perusahaan dan bagaimana posisi perusahaan di masa depan serta untuk mengidentifikasi ancamanancaman yang mungkin terjadi.

\section{Balanced Scorecard}

Menurut Guan, Hansen dan Mowen (2009: p468) Balanced Scorecard adalah sistem manajemen strategi yang mengindentifikasi tujuan dan mengukur kedalam empat perspektif: perspektif keuangan, perspektif pelanggan, perspektif proses bisnis internal, dan perspektif pertumbuhan dan pembelajaran.

Menurut Robert Kaplan dan David Norton, balanced scorecard adalah suatu sistem pengukuran yang memungkinkan perusahaan atau organisasi untuk melakukan klarifikasi strategi, menerjemahkan kedalam action dan menghasilkan suatu feedback yang berarti. Balanced Scorecard adalah suatu konsep manajemen yang membantu menerjemahkan strategi kedalam tindakan. Balanced Scorecard adalah lebih dari 
sekedar suatu sistem pengukuran operasional atau taktis.

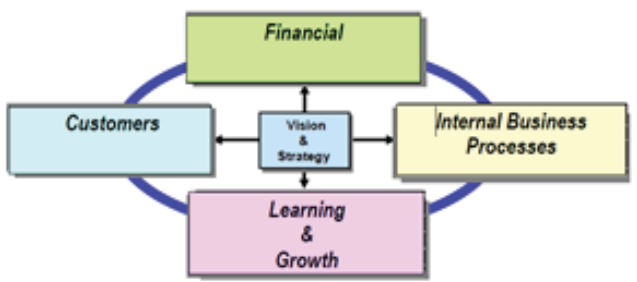

Gambar 1. Empat Perspektif Balanced Scorecard

(Sumber: Kaplan, Robert S.2010, Conceptual Foundations of Balanced Scorecard)

Kaplan dan Norton memperkenalkan empat perspektif yang seimbang dan berbeda dari suatu aktivitas perusahaan yang dapat dievaluasi oleh manajemen sebagai berikut:

1. Perspektif keuangan - bagaimana kita memuaskan pemegang saham ?

2. Perspektif pelanggan - bagaimana kita memuaskan pelanggan?

3. Perspektif proses bisnis internal - apa proses-proses yang sebaiknya diunggulkan untuk mencapai kesuksesan perusahaan?

4. Perspektif pembelajaran dan pertumbuhan - bagaimana kita akan mempertahankan keberlangsungan kemampuan terhadap perubahan dan peningkatan?

\section{Fishbone Diagram}

Menurut Dale (2007) diagram fishbone yang tepatnya sebuah metode/tool yang disebut dengan diagram tulang ikan (fishbone diagram). Atau sering juga disebut dengan diagram sebab akibat (cause effect diagram). Penggagasnya adalah seorang ilmuwan Jepang pada tahun 60 -an. Bernama Dr. Kaoru Ishikawa, ilmuwan kelahiran 1915 di Tokyo Jepang yang juga alumni teknik kimia Universitas Tokyo. Sehingga sering juga disebut dengan diagram ishikawa. Umumnya penggunaan fishbone untuk design produk dan mencegah kualitas produk yang jelek (defect).

\section{Performance Dashboard}

Pada dasarnya performance dashboard adalah suatu laporan yang efektif yang dirancang dengan mengembangkan sebuah laporan yang menampilkan semua KPI penting dalam format presentasi visual, dalam bentuk grafik, diagram dan tabel (Alexander, 2007). Laporan dashboard harus tersusun simpel dan mudah dipahami oleh manajer maupun para karyawan. Dashboard menyampaikan informasi mengenai aspekaspek utama dari perusahaan untuk mengetahui posisi kinerja perusahaan dan bagaimana posisi perusahaan di masa depan serta untuk mengidentifikasi ancamanancaman yang mungkin terjadi.

\section{METODOLOGI PENELITIAN}

\section{Kerangka Pikir}

Metodologi yang digunakan adalah dengan menganalisa kondisi saat ini, menganalisa strategi bisnis yang ada menggunakan balance scorecard, dan akan menggunakan performance dashboard yang sesuai untuk memudahkan proses pengukuran kinerja organisasi dan bisnis unit serta key performance indicators dari setiap individu.

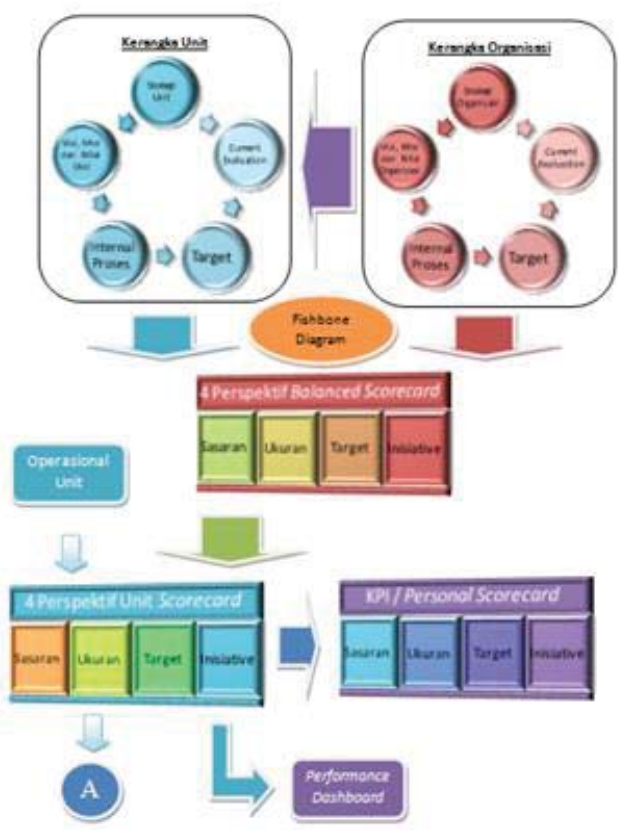

Gambar 2. Kerangka pikir bagian 1

\section{Proses Audit}

Setelah melakukan analisa terhadap semua perspektif balanced scorecard maka akan dilakukan audit guna mengenali, 
mengidentifikasi dan menguji hasil dari penelitian yang dilakukan sebelumnya secara detail informasi dan fakta-fakta yang ada untuk mengungkap kejadian yang sebenarnya dalam rangka pembuktian.

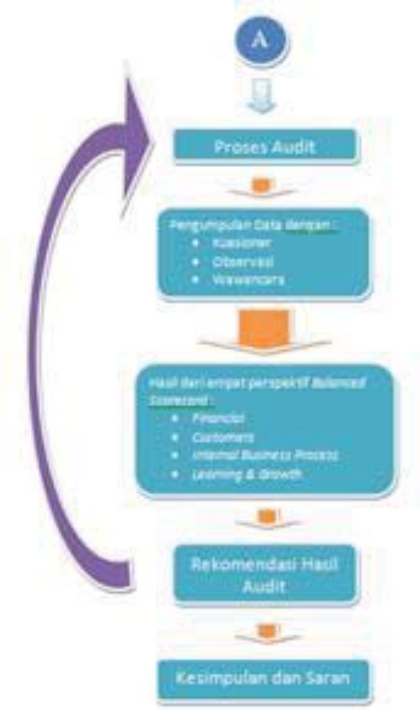

Gambar 3. Kerangka pikir bagian 2

\section{Pengumpulan Data}

Guna mengenali dan mengidentifikasi secara mendetail maka dilakukan pengumpulan data dan informasi yang terkait dengan penelitian dengan menggunakan:

1. Kuesioner

2. Observasi

3. Wawancara

\section{Hasil dari Empat Perspektif Balanced Scorecard}

Setelah melakukan pengumpulan data dan menganalisa keseluruhan perspektif balanced scorecard pada strategi bisnis perusahaan, strategi bisnis unit dan personal scorecard maka dilakukan audit terhadap data tersebut dengan pendekatan empat perspektif balanced scorecard:

1. Financial (Keuangan)

2. Customer (Pelanggan)

3. Internal Process (Proses Internal)

4. Learning \& Growth (Pembelajaran \& Pertumbuhan)

\section{HASIL DAN PEMBAHASAN}

\section{Analisa SWOT Strategi Bisnis Organisasi \\ Analisa SWOT (Strengths,} Weaknesses, Opportunities, dan Threats) yang digunakan untuk menentukan arah pengembangan strategi bisnis, visi, misi dan nilai organisasi perusahaan PT. Kebayoran Pharma diturunkan ke bisnis unit divisi Hoslab sehingga dapat terlihat jelas arah pengembangan strategi bisnis visi, misi dan nilai unit kerja divisi Hoslab. Analisis dari SWOT tersebut adalah sebagai berikut:

\begin{tabular}{|c|c|c|}
\hline SWOT & $\begin{array}{l}\text { Current Evaluation } \\
\text { Organisasi }\end{array}$ & $\begin{array}{l}\text { Current Evaluation Unit Kerja } \\
\text { Divisi Hoslab }\end{array}$ \\
\hline $\begin{array}{l}\text { Strengths/ } \\
\text { Kekuatan }\end{array}$ & $\begin{array}{l}\text { 1. Kualitas dan layanan } \\
\text { delivery yang tepat waktu } \\
\text { 2. Infrastruktur distribusi } \\
\text { yang luas } \\
\text { 3. Adanya Customer Service } \\
\text { dalam pelayanan }\end{array}$ & $\begin{array}{l}\text { 1. } \begin{array}{l}\text { Layanan CITO (segera) dan } \\
\text { pembagian layanan per } \\
\text { wilayah rayon }\end{array} \\
\text { 2. Produk dapat dilayani di } 30 \\
\text { cabang di Indonesia }\end{array}$ \\
\hline $\begin{array}{l}\text { Weaknesses / } \\
\text { Kelemahan }\end{array}$ & $\begin{array}{l}\text { 1. Belum terkomunikasikan } \\
\text { dengan baik rencana } \\
\text { strategi bisnis dari top } \\
\text { level ke karyawan } \\
\text { 2. Belum adanya tolak ukur } \\
\text { dalam mengevaluasi } \\
\text { kinerja unit kerja maupun } \\
\text { karyawan }\end{array}$ & $\begin{array}{l}\text { 1. } \begin{array}{l}\text { Karyawan divisi Hoslab } \\
\text { bekerja tanpa adanya rencana } \\
\text { strategi bisnis }\end{array} \\
\text { 2. Divisi Hoslab tidak memiliki } \\
\text { tolak ukur kinerja, target dan } \\
\text { Key Performance Indicator } \\
\text { (KPI) per karyawan }\end{array}$ \\
\hline $\begin{array}{l}\text { Opportunities / } \\
\text { Peluang }\end{array}$ & $\begin{array}{l}\text { 1. Adanya peluang untuk } \\
\text { meningkatkan efisiensi } \\
\text { dan efektivitas kinerja unit } \\
\text { kerja dan karyawan }\end{array}$ & $\begin{array}{ll}\text { 1. } & \text { Adanya peluang } \\
\text { meningkatkan efisiensi biaya } \\
\text { pengiriman antar cabang dan } \\
\text { efektivitas kinerja setiap } \\
\text { karyawan }\end{array}$ \\
\hline $\begin{array}{c}\text { Threats / } \\
\text { Ancaman }\end{array}$ & $\begin{array}{l}\text { 1. Biaya operasional yang } \\
\text { semakin tinggi } \\
\text { 2. Banyaknya perusahaaan } \\
\text { lain yang bergerak } \\
\text { dibidang yang sama. }\end{array}$ & $\begin{array}{l}\text { 1. Biaya pengiriman ke luar kota } \\
\text { yang terus meningkat } \\
\text { 2. Banyaknya perusahaan } \\
\begin{array}{l}\text { dengan Produk yang serupa } \\
\text { dengan divisi Hoslab }\end{array}\end{array}$ \\
\hline
\end{tabular}

Gambar 4. Analisa SWOT current evaluation organisasi diturunkan ke current evaluation bisnis unit kerja divisi Hoslab

Setelah hasil analisis current evaluation SWOT yang dilakukan menghasilkan faktor-faktor internal (Strengths dan Weaknesses) dan eksternal (Opportunities dan Threats), maka berdasarkan hasil tersebut digunakan untuk menentukan strategi-strategi bisnis dalam sebuah perusahaan (Freddy Rangkuti) yaitu:

1. Strategi SO, dengan mengembangkan suatu strategi dengan memanfaatkan kekuatan (S) untuk mengambil manfaat dari peluang $(\mathrm{O})$ yang ada

2. Strategi WO, mengembangkan suatu strategi dalam memanfaatkan peluang (O) untuk mengatasi kelemahan (W) yang ada. 
3. Strategi ST, dengan mengembangkan suatu strategi dalam memanfaatkan kekuatan (S) untuk menghindari ancaman (T).

4. Strategi WT, dengan mengembangkan suatu strategi dalam mengurangi kelemahan (W) dan menghindari ancaman $(\mathrm{T})$.

\begin{tabular}{|c|c|c|}
\hline $\begin{array}{r}\text { Faktor } \\
\text { Internal }\end{array}$ & $\begin{array}{l}\text { (S) Strengths/ } \\
\text { Kekuatan }\end{array}$ & $\begin{array}{c}\text { (W) Weaknesses / } \\
\text { Kelemahan }\end{array}$ \\
\hline $\begin{array}{c}\text { (0) } \\
\text { Opportunitie } \\
\text { s / Peluang }\end{array}$ & $\begin{array}{ll}\text { 1. } & \begin{array}{l}\text { Meningkatkan } \\
\text { pelayanan } \\
\text { distribusi }\end{array} \\
\text { 2. } & \begin{array}{l}\text { Meningkatkan } \\
\text { infrastruktur } \\
\text { distribusi }\end{array} \\
\text { 3. } & \begin{array}{l}\text { Customer } \\
\text { Service } \\
\text { berkualitas }\end{array}\end{array}$ & 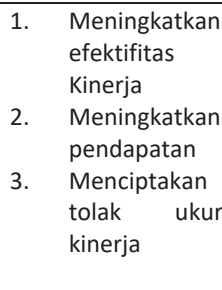 \\
\hline $\begin{array}{l}\text { (T) Threats / } \\
\text { Ancaman }\end{array}$ & $\begin{array}{ll}\text { 1. } & \text { Meningkatkan } \\
\text { efesiensi biaya } \\
\text { 2. Meningkatkan } \\
\text { persaingan } \\
\text { produk }\end{array}$ & $\begin{array}{ll}\text { 1. } & \text { Menciptakan } \\
\text { strategi bisnis } \\
\text { 2. } \\
\text { Menciptakan } \\
\text { target bisnis }\end{array}$ \\
\hline
\end{tabular}

Gambar 5. Strategi Bisnis Divisi Hoslab berdasarkan analisa SWOT

\section{Analisa Value Chain Internal Phase}

Untuk mendapatkan rantai nilai (value chain) dari internal proses unit kerja divisi Hoslab diperlukan analisa internal proses organisasi PT Kebayoran Pharma yang diturunkan ke internal proses unit kerja divisi Hoslab sehingga dihasilkan value chain yang dapat membantu dalam menciptakan nilai dan keuntungan kompetitif untuk seluruh internal proses unit kerja divisi Hoslab:

1. Kegiatan Premier

\section{- Inbound Logistic}

- Stok produk yang masuk ke dalam gudang pusat Hoslab hanya merupakan stok yang cepat jual sehingga tidak menghabiskan ruang penyimpanan yang terlalu besar.

- Produk yang akan masuk ke gudang Hoslab merupakan produk yang telah dipesan pelanggan dan produk yang cepat jual sehingga meminimalisir biaya pengiriman.

- Operations

- Pengiriman produk disesuaikan dengan rayon FCS (Field Customer Service) sehingga tidak menimbulkan biaya yang terlalu besar dikarenakan jauhnya pengiriman.

- Sebelum dilakukannya penagihan ke pelanggan, konfirmasi dahulu via telepon sehingga FCS tidak sia-sia menemui pelanggan.

- Outbound Logistic

- Biaya pengiriman ke luar kota memperhitungkan besarnya nilai produk yang akan dikirim sehingga tidak menimbulkan kerugian.

- $\quad$ Sales \& Marketing

- Analisa forecasting untuk dicabang tidak jauh dari kenyataan sehingga tidak menimbulkan over stock dan produk kadaluarsa di cabang.

- Menciptakan order dari pelanggan yang belum pernah membeli sehingga dapat meningkatkan penjualan.

- Services

- Meningkatkan pelayanan dengan 2 kali pengantaran pagi dan siang hari di setiap wilayah rayon.

- Memberikan jaminan kepada pelanggan berupa voucher diskon jika pengantaran CITO (segera) mengalami keterlambatan.

2. Kegiatan Pendukung

- Support Activities Infrastructure

- Menambah fasilitas pengantaran berupa kotak box barang di setiap armada pengantar (FCS).

- Menambah insentive untuk setiap karyawan yang telah menyelesaikan tugasnya sesuai dengan Key Performance Indicator (KPI).

- Diperketat aturan yang sesuai dengan Standard Operational 
Procedure (SOP) sehingga menjadi acuan operasional.

- Human Resource Management

- Diadakan training untuk setiap karyawan sehingga dapat mengembangkan disetiap pekerjaannya.

- Setiap karyawan yang berpotensi diikut sertakan dalam seminar nasional maupun internasional guna pengembangan profesi.

- Product\&Technology Management

- Mengembangkan SI/TI untuk meningkatkan pelayanan ke pelanggan maupun principal seperti CRM, E-Commerce, mobile transaction, dan lainlain.

\section{Procurement}

- Pengadaan maintenance untuk setiap armada pengantar sehingga tampil prima untuk layanan pengantaran.

\section{Empat Perspektif Unit Scorecard}

Empat perspektif unit scorecard akan dianalisa menggunakan pendekatan SMART, menurut Rampersad (2005, p70) tujuan target pengukuran kinerja sangat penting untuk memenuhi kriteria SMART:

1. Specific : Tujuan harus dinyatakan dengan spesifik dan secara tegas.

2. Measureable : Tujuan harus dapat diukur dengan menggunakan indikator pengukuran yang tepat guna mengevaluasi keberhasilan, peninjauan ulang, tindakan perbaikan di masa mendatang. Pengukuran harus dapat memunculkan fakta-fakta yang dinyatakan secara kuantitatif menggunakan angka-angka.

3. Achievable: Tujuan harus dapat dicapai melalui usaha-usaha dalam programprogram peningkatan kinerja yang menantang.

4. Result : Tujuan harus berfokus pada hasil-hasil berupa pencapaian targettarget kinerja yang telah ditetapkan.

5. Time-bound : Tujuan harus dapat dicapai sesuai batas waktu yang ditetapkan.

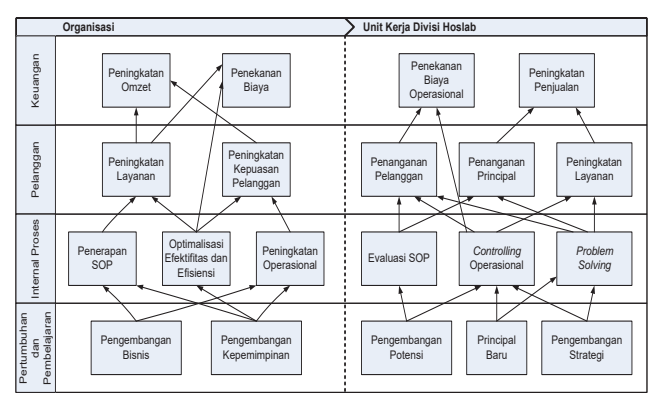

Gambar 6. A Strategy Map Represent How the Organization Creates Value

Gambar berikut merupakan peta strategi organisasi dan unit kerja divisi Hoslab berdasarkan empat perspektif balanced scorecard guna mendukung nilai bisnis dan kontribusi strategis (Wibisono, Eric). Sehingga dihasilkan strategi bisnis yang lebih objektif dan terarah. Diharapkan nantinya mampu menciptakan strategi untuk unit kerja divisi Hoslab yang mengarah ke key performance indicator per karyawan sehingga strategi yang akan diterapkan oleh perusahaan mampu diterapkan oleh karyawan khususnya team unit kerja divisi Hoslab:

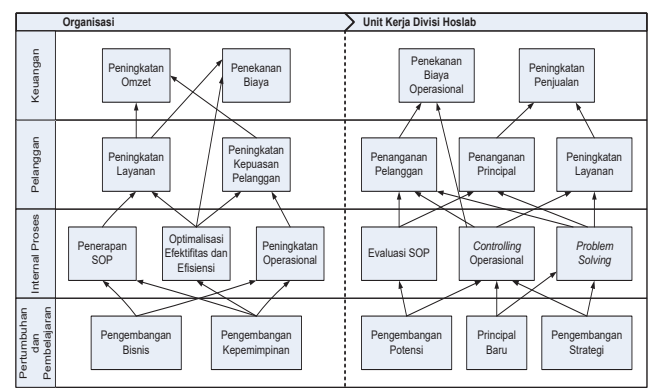

Gambar 7. Strategic Map Empat Perspektif Balanced Scorecard

\section{Perancangan Key Performance Indicator}

Pada tahap analisa ini akan ditentukan KPI, tolak ukur kinerja, target dan inisiatif strategis unit kerja divisi Hoslab serta karyawan pada unit kerja divisi Hoslab menggunakan empat perspektif unit balanced scorecard. Sehingga dapat dihasilkan pengukuran kinerja yang lebih komprehensif dan terukur yang mampu menyampaikan visi, misi, target dan nilai-nilai organisasi dari tingkat management hingga ke level karyawan: 


\begin{tabular}{|c|c|c|c|c|}
\hline Tujuan (Fokus) & KPI's & Tolak Ukur Kinerja & Target 2013 & Inisiatif Strategis \\
\hline \multirow[t]{3}{*}{ Keuangan } & Biaya operasional & $\begin{array}{l}\text { Menghemat biaya } \\
\text { operasional bulanan }\end{array}$ & $\begin{array}{lr}\text { Peningkatan } & \text { biaya } \\
\text { operasional } & \text { tidak } \\
\text { melebihi } 10 \% \text { dari tahun } \\
2012\end{array}$ & $\begin{array}{l}\text { Meningkatkan } \\
\text { pengawasan } \\
\text { operasional }\end{array}$ \\
\hline & Peningkatan penjualan & $\begin{array}{l}\text { Tercapainya target yang } \\
\text { ditentukan } \\
\text { bulannya }\end{array}$ & $\begin{array}{l}\text { Penjualan mencapai } 5 \\
\text { Milyar setiap bulannya }\end{array}$ & $\begin{array}{l}\text { Peninjauan lomjungan } \\
\text { customer baru setiap } \\
\text { minggu }\end{array}$ \\
\hline & Penyelesaian piutang & Berkurangnya piutang & $\begin{array}{l}\text { Tidak melebihi } R p \\
250.000 .000 \text { perbulan }\end{array}$ & $\begin{array}{l}\text { Melakukan pendekatan ke } \\
\text { pelanggan }\end{array}$ \\
\hline \multirow[t]{3}{*}{ Pelanggan } & Kepuasan pelanggan & $\begin{array}{l}\text { Jumlah } \\
\text { pelanggan } \\
\text { dilaporkan }\end{array}$ & $\begin{array}{l}\text { Maksimal } 5 \text { keluhan } \\
\text { perbulan pelanggan yang } \\
\text { complain }\end{array}$ & $\begin{array}{l}\text { Memenuhi keinginan } \\
\text { pelanggan sesuai dengan } \\
\text { peraturan perusahaan }\end{array}$ \\
\hline & $\begin{array}{l}\text { Peningkatan pelayanan } \\
\text { pelanggan }\end{array}$ & \begin{tabular}{lr} 
Jumlah & \multicolumn{2}{c|}{ terpenuhinya } \\
pesanan & sesuai \\
yang diinginkan
\end{tabular} & $\begin{array}{l}\text { Maksimal } 3 \text { pesanan yang } \\
\text { tertunda dalam sebulan }\end{array}$ & $\begin{array}{l}\text { Menyediakan pengantar } \\
\text { pagi dan sore serta } \\
\text { pengantar CITO (segera) }\end{array}$ \\
\hline & Kepuasan principal & $\begin{array}{l}\text { Jumlah keluhan principal } \\
\text { yang dilaporkan }\end{array}$ & $\begin{array}{l}\text { Maksimal } 5 \\
\text { dalam sebulan }\end{array}$ & $\begin{array}{l}\text { Memenuhi keinginan } \\
\text { principal sesuai dengan } \\
\text { peraturan perusahaan }\end{array}$ \\
\hline Tujuan (Fokus) & KPI's & Tolak Ukur Kinerja & Target 2013 & Inisiatif Strategis \\
\hline \multirow[t]{4}{*}{ Internal Proses } & $\begin{array}{l}\text { Kualitas pengiriman ke } \\
\text { pelanggan dalam kota }\end{array}$ & $\begin{array}{l}\text { Jumlah kesalahan } \\
\text { pengiriman dalam kota }\end{array}$ & $\begin{array}{l}\text { Maksimal } 3 \text { kali } \\
\text { kesalahan pengiriman } \\
\text { dalam sebulan }\end{array}$ & $\begin{array}{l}\text { Kejelasan pemesanan dan } \\
\text { konfirmasi ulang jika } \\
\text { perlu }\end{array}$ \\
\hline & $\begin{array}{l}\text { Kualitas pengiriman ke } \\
\text { cabang luar kota }\end{array}$ & $\begin{array}{l}\text { Jumlah kesalahan } \\
\text { pengiriman luar kota }\end{array}$ & $\begin{array}{l}\text { Maksimal } 3 \text { kali } \\
\text { kesalahan pengiriman } \\
\text { dalam sebulan }\end{array}$ & $\begin{array}{l}\text { Kejelasan pemesanan dan } \\
\text { konfirmasi ulang jika } \\
\text { perlu }\end{array}$ \\
\hline & $\begin{array}{l}\text { Rutinitas penagihan } \\
\text { piutang ke pelanggan }\end{array}$ & $\begin{array}{l}\text { Jumlah kunjungan ke } \\
\text { outlet }\end{array}$ & $\begin{array}{l}\text { Minimal kunjungan ke } \\
\text { outlet seminggu } 2 \text { sekali }\end{array}$ & $\begin{array}{l}\text { Review DTH (daftar } \\
\text { tagihan harian) seminggu } \\
\text { sekali }\end{array}$ \\
\hline & $\begin{array}{l}\text { Estimasi stock cabang } \\
\text { luar kota }\end{array}$ & $\begin{array}{l}\text { Jumlah pengiriman CITO } \\
\text { ke cabang luar kota }\end{array}$ & $\begin{array}{l}\text { Maksimal } 20 \quad \text { kali } \\
\text { pengiriman } \\
\text { sebulan }\end{array}$ & $\begin{array}{l}\text { Pengawasan stock di } \\
\text { cabang dengan review } \\
\text { per produk }\end{array}$ \\
\hline \multirow[t]{7}{*}{$\begin{array}{l}\text { Pembelajaran dan } \\
\text { Pertumbuhan }\end{array}$} & $\begin{array}{l}\text { Pengembangan potensi } \\
\text { karyawan }\end{array}$ & $\begin{array}{l}\text { Jumlah pengembangan } \\
\text { tugas setiap karyawan }\end{array}$ & $\begin{array}{l}\text { Setiap karyawan } \\
\text { mengembangkan } \\
\text { tugasnya minimal } 2 \text { kali } \\
\text { dalam sebulan }\end{array}$ & $\begin{array}{l}\text { Review tugas karyawan } \\
\text { dan memberikan } \\
\text { masukan pengembangan }\end{array}$ \\
\hline & $\begin{array}{l}\text { Penyelesaian } \\
\text { karyawan }\end{array}$ & Waktu pengerjaan tugas & $\begin{array}{l}\text { Maksimal } 6 \text { hari dalam } \\
\text { sebulan }\end{array}$ & $\begin{array}{l}\text { Memberi masukan cara } \\
\text { yang cepat }\end{array}$ \\
\hline & Absensi karyawan & $\begin{array}{l}\text { Jumlah kehadiran dalam } \\
\text { sebulan }\end{array}$ & $\begin{array}{l}\text { Dalam } 3 \text { bulan tidak ada } \\
\text { absensi tidak masuk }\end{array}$ & $\begin{array}{l}\text { Review dan memberikan } \\
\text { masukan }\end{array}$ \\
\hline & $\begin{array}{l}\text { Keterlambatan kehadiran } \\
\text { karyawan }\end{array}$ & $\begin{array}{l}\text { Jumlah keterlambatan per } \\
\text { karyawan }\end{array}$ & $\begin{array}{lr}\begin{array}{l}\text { Maksimal } \\
\text { keterlambatan } \\
\text { sebulan }\end{array} & \begin{array}{r}\text { kali } \\
\text { dalam }\end{array} \\
\end{array}$ & $\begin{array}{l}\text { Review dan memberikan } \\
\text { masukan }\end{array}$ \\
\hline & $\begin{array}{l}\text { Penyelesaian| } \\
\text { permasalahan }\end{array}$ & $\begin{array}{l}\text { Waktu penyelesaian } \\
\text { permasalahan }\end{array}$ & Maksimal 6 hari & $\begin{array}{l}\text { Review dan memberikan } \\
\text { masukan }\end{array}$ \\
\hline & $\begin{array}{l}\text { Penambahan principal } \\
\text { guna pengembangan } \\
\text { bisnis Hoslab }\end{array}$ & $\begin{array}{l}\text { Jangka waktu } \\
\text { penambahan principal }\end{array}$ & $\begin{array}{l}\text { Minimal } 3 \text { principal } \\
\text { dalam waktu setahun }\end{array}$ & $\begin{array}{l}\text { Memberikan referensi } \\
\text { principal yang layak }\end{array}$ \\
\hline & $\begin{array}{l}\text { Peningkatan } \\
\text { karyawan }\end{array}$ & $\begin{array}{l}\text { Jumlah KPI yang dapat } \\
\text { dipenuhi karyawan }\end{array}$ & $\begin{array}{l}\text { Minimal } 15 \text { KPI dipenuhi } \\
\text { karyawan }\end{array}$ & $\begin{array}{l}\text { Memberikan } \\
\text { insentif KPI }\end{array}$ \\
\hline
\end{tabular}

Gambar 8. Perancangan KPI divisi Hoslab

\section{Pembobotan KPI}

Pembobotan perspektif keuangan ditetapkan paling besar mengingat tujuan utama pengukuran kinerja berada pada perspektif ini. Selain itu, penetapan anggaran berbasis kinerja pada umumnya juga dikaitkan dengan KPI pada perspektif ini. Pertimbangannya adalah output/outcome final yang ingin dicapai oleh suatu unit telah terefleksi secara kuantitatif pada perspektif keuangan.

Sebagaimana perspektif keuangan, bobot perspektif pertumbuhan dan pembelajaran juga dihitung sama besarnya. Hal ini didasari bahwa perspektif inilah yang merupakan cikal bakal penentu kinerja organisasi secara keseluruhan dalam jangka panjang.
Penetapan perspektif internal proses yang kecil bukan didasarkan pada kurangnya peranan perspektif ini dalam meningkatkan kinerja unit, akan tetapi perspektif ini adalah merupakan tindak lanjut dari keberhasilan kinerja perspektif pertumbuhan dan pembelajaran.

Untuk perspektif pelanggan, sebagaimana fungsi organisasi publik yaitu memberikan pelayanan, maka diberikan bobot sebesar $25 \%$.

Tabel 1. Pembobotan Nilai KPI divisi Hoslab

\begin{tabular}{lc}
\hline Key Performance Indicator & Bobot \\
\hline Perspektif Keuangan (30\%) & \\
Biaya operasional & $10 \%$ \\
Peningkatan penjualan & $10 \%$
\end{tabular}


Penyelesaian piutang

Perspektif Pelanggan (25\%)

Kepuasan pelanggan

$10 \%$

Peningkatan pelayanan pelanggan $\quad 10 \%$

Kepuasan principal

$5 \%$

Perspektif Internal Proses (15\%)

Kualitas pengiriman ke pelanggan

dalam kota

Kualitas pengiriman ke cabang luar

kota

Rutinitas penagihan piutang ke

pelanggan

Estimasi stock cabang luar kota

$3 \%$

$5 \%$

$4 \%$

$3 \%$

Perspektif Pertumbuhan dan Pembelajaran

(30\%)

Pengembangan potensi karyawan $\quad 5 \%$

Penyelesaian tugas karyawan $\quad 4 \%$

Absensi karyawan $\quad 4 \%$

Keterlambatan kehadiran karyawan $\quad 4 \%$

Penyelesaian permasalahan yang $\quad 5 \%$

dihadapi karyawan

Penambahan principal guna $\quad 4 \%$

pengembangan bisnis Hoslab

Peningkatan kinerja karyawan

Analisa Performance Dashboard

Menurut Alexander

Dashboard menyampaikan informasi

mengenai aspek-aspek utama dari perusahaan untuk mengetahui posisi kinerja

perusahaan dan bagaimana posisi perusahaan dimasa depan serta untuk mengidentifikasi ancaman-ancaman yang mungkin terjadi.

Dalam bisnis unit perusahaan diperlukan adanya analisa performance dashboard guna mengetahui seberapa besar peran informasi yang disampaikan dalam operasional yang dijalankan bisnis unit dengan menerapkan performance dashboard. Singkatnya, apa yang benarbenar dibutuhkan perusahaan ialah Performance Dashboard yang menterjemahkan strategi perusahaan kedalam tujuan, metrik, inisiatif dan tugas yang disesuaikan untuk setiap kelompok dan individu dalam organisasi. Sebuah Performance Dashboard mengkomunikasikan tujuan strategis dan memungkinkan pelaku bisnis untuk mengukur, memantau, dan mengelola kegiatan utama dan proses yang diperlukan untuk mencapai tujuan organisasi (Eckerson 2005, p3).
1. Arsitektur Performance Dashboard Arsitektur performance dashboard unit kerja divisi Hoslab mulai dari sumber data, middle layer (untuk integrasi data), analytical tools sampai dengan penyajian.

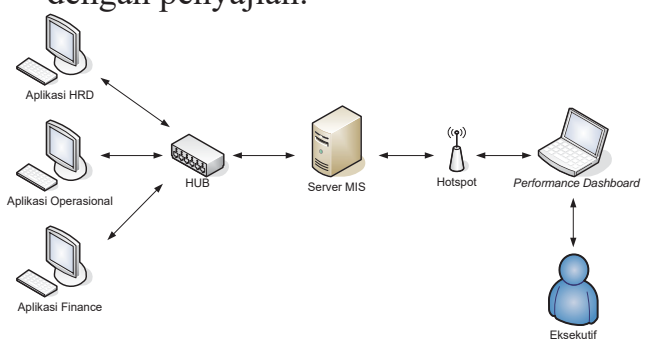

Gambar 9. Arsitektur Performance

Dashboard unit kerja divisi Hoslab

2. Design Performance Dashboard

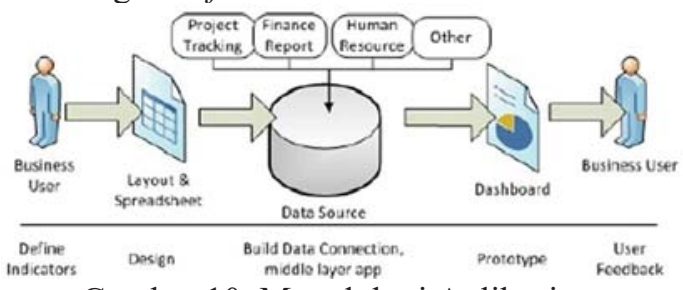

Gambar 10. Metodologi Aplikasi

Performance Dashboard

3. Tampilan Performance Dashboard

Tampilan dari dashboard

biasanya terdiri dari 3 layer informasi yang berguna bagi user, yaitu:

- Kesimpulan keseluruhan kegiatan berupa tampilan data statistic atau grafik (KPI)

- Informasi multidimensional (misal : waktu, pelanggan, sales, dll) dan tampilan hirarki (misal : bagian, operation area, dll)

- Tampilan yang lebih detail seperti faktur, piutang, dll.

4. Tampilan Home Screen

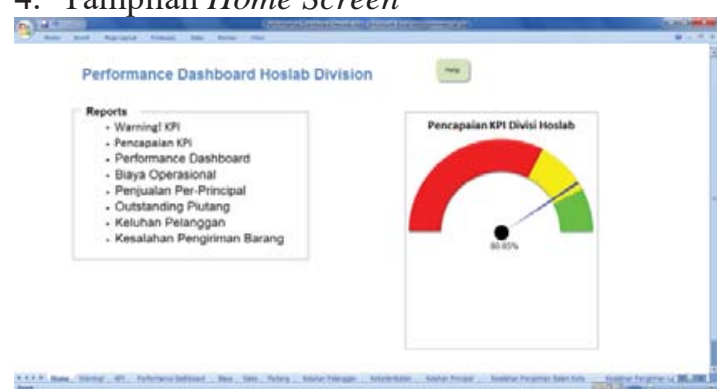

Gambar 11. Tampilan Home Screen

Pada tampilan home screen terdapat menu reports untuk memilih 
laporan secara lebih detail, yaitu:

○ Warning KPI

○ Pencapaian KPI

- Performance Dashboard

- Biaya Operasional

- Penjualan Per-Principal

○ Outstanding Piutang

- Keluhan Pelanggan

- Kesalahan Pengiriman Barang

5. Tampilan Warning KPI

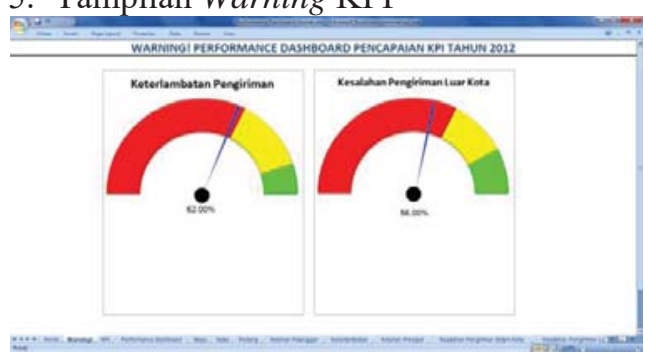

Gambar 12. Tampilan Warning KPI

Tampilan warning! KPI, menyajikan pencapaian KPI yang termasuk dalam indicator merah dimana KPI ini harus menjadi perhatian lebih dan tingkat kewaspadaan yang tinggi dari para eksekutif sehingga dapat diambil keputusan yang cepat dan perbaikan strategi yang tepat, untuk memperbaiki kinerja para karyawan khususnya divisi Hoslab. Batasan indicator setiap KPI berbeda-beda sesuai dengan target dan tingkat kewaspadaan yang dibutuhkan oleh para eksekutif untuk mengambil keputusan yang tepat.

6. Tampilan Pencapaian KPI

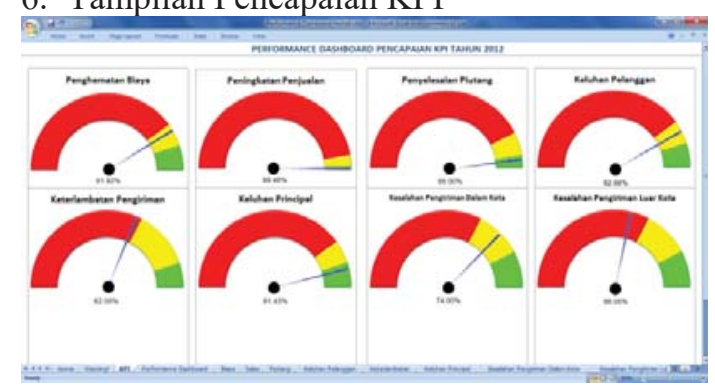

Gambar 13. Tampilan Pencapaian KPI

Untuk memantau seluruh pencapaian KPI di divisi Hoslab disediakan tampilan pencapaian KPI yang dapat menyajikan pencapaian KPI di setiap bagian di divisi Hoslab, dengan menganalisa hasil dari KPI masingmasing pengukuran didapatkan suatu kesimpulan hasil kinerja maupun potensi yang diperoleh, sehingga para eksekutif dapat merancang strategi selanjutnya untuk memperbaiki kinerja para karyawan. Untuk indicator disetiap pencapaian KPI berbed-beda sesuai dengan target dan tingkat kewaspadaan yang dibutuhkan oleh para eksekutif untuk mengambil suatu keputusan yang cepat dan tepat.

\section{Tampilan Performance Dashboard}

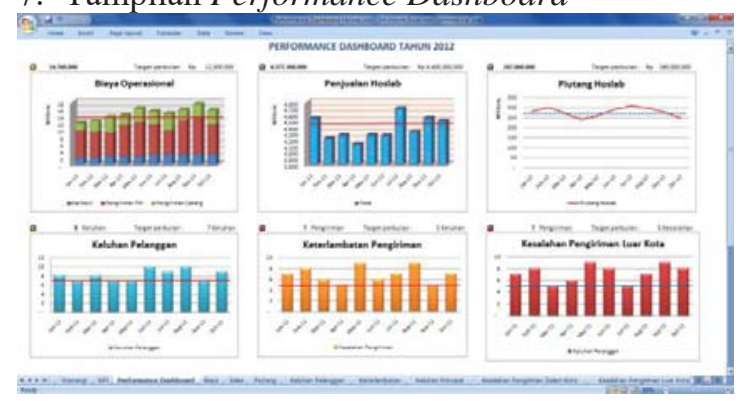

Gambar 14. Tampilan Performance Dashboard

Tampilan

Performance

Dashboard mewakilkan laporan kinerja unit kerja dvisi Hoslab secara keseluruhan yang berupa grafik, chart dan indicator guna pengawasan yang lebih maksimal, sehingga para eksekutif dapat mengambil keputusan dengan cepat. Indikator pada laporan menunjukkan tingkat kewaspadaan/alert:

○ Merah - Tingkat kewaspadaan tinggi

○ Kuning - Tingkat kewaspadaan menengah

- Hijau - Masih dalam batas aman Indikator-indikator tersebut ditentukan dalam target maupun kebijakan perusahaan oleh para eksekutif, sehingga telah sesuai dengan strategi unit kerja divisi Hoslab.

\section{KESIMPULAN DAN SARAN}

\section{Kesimpulan}

Dari hasil penelitian dan pembahasan yang telah dilakukan maka dapat disimpulkan dari perancangan konsep Balanced Scorecard di PT. Kebayoran Pharma adalah sebagai berikut:

1. Anggapan dari manajemen dan 
karyawan bahwa penerapan metode Balance Scorecard di organisasi perusahaan PT. Kebayoran Pharma merupakan sesuatu yang sulit dan rumit. Proyek Balance Scorecard di Hospital \& Laboratory Division dijadikan contoh untuk ditunjukan kepada divisi lain bahwa Balance Scorecard berguna bagi organisasi.

2. Proyek Balance Scorecard di PT. Kebayoran Pharma membuktikan divisi Hoslab berperan aktif dalam mencapai visi dan misi perusahaan.

3. Balance Scorecard dapat mendeteksi prioritas strategik objektif dan potensial strategik objektif yang perlu dikembangkan oleh divisi Hoslab PT. Kebayoran Pharma di masa mendatang.

4. Implementasi Key Performance Indicator dengan metode Balance Scorecard menjadi panduan sehingga memampukan karyawan di Hoslab Division melewati proses perubahan yang sedang dijalani.

\section{Saran}

Berdasarkan atas kesimpulan diatas maka dapat diberikan beberapa saran yang dapat digunakan untuk pengembangan dan penerapan dari Key Performance Indicator dengan konsep Balance Scorecard pada PT. Kebayoran Pharma sebagai berikut:

1. Menjalankan proyek Balance Scorecard di Hoslab division PT. Kebayoran Pharma dengan konsisten dan mendapat dukungan dari manajemen puncak serta mempublikasikan kemajuan proyek tersebut ke divisi lain.

2. Hoslab division sebagai kontributor strategik harus mengadakan pertemuan rutin untuk mengevaluasi dan mengembangkan fungsi strategiknya dalam mencapai visi dan misi perusahaan.

3. Mengembangkan rencana kerja untuk memenuhi target dari prioritas strategik objektif dan mengembangkan pengukuran untuk potensial strategik yang objektif.

4. Penerapan dari Balance Scorecard proyek harus dilengkapi dengan reward and punishment untuk menjaga kestabilan dari proses perubahan.

\section{DAFTAR PUSTAKA}

Alexander, Jack (2007). Performance Dashboard and Analysis for Value Creation, Library of Cogress Cataloging-in-Publication Data, Canada.

Dale, Berrie G; Ton Van Der Wiele; Jos Van Iwaarden, (2007), Managing Quality; 5th Edition, John Wiley \& Sons.

Eckerson, Wayne (2005), Performance Dashboards: Measuring, Monitoring, and Managing Your Business, John Wiley \& Sons.

Freddy Rangkuti (2005), Analisis SWOT : Teknik Membedah Kasus Bisnis, Gramedia Pustaka Utama, Jakarta.

Guan, Liming; Don R. Hansen dan Maryanne M. Mowen. (2009). Cost Management : 6th Edition, SouthWestern Cengage Laerning, USA.

Harnanda, Silma Luthfika (2013), Analisis Pengukuran Kinerja Sumber Daya Manusia Menggunakan Metode Human Resoureces Scorecard (Studi Kasus Di PT. Erindo Mandiri, Pasuruan)

(http://skripsitip.staff.ub.ac.id/files/2 013/08/Jurnal-Silma-L.H.pdf)

Kaplan, Robert S., (2010), Conceptual Foundations of Balanced Scorecard, Harvard Business School, Boston Massachussets.

Kaplan, Robert S., and Norton, P. David (2004), Strategy Maps : Converting Intangible Assets into Tangible Outcomes, Harvard Business School Press, Boston Massachussets.

Kaplan, Robert S. and Norton P. David (2008), Mastering the Management System, Harvard Business School, Boston Massachussets

Kaplan, Robert S., and Norton, P. David (2010), The Strategy Focused Organization : How Balanced 
Scorecard Companies Thrive in the New Business, Harvard Business School Press, Boston Massachussets.

Morrison, Mike (2010), Critical Success Factor - Analysis, RapidBI, (http://rapidbi.com/criticalsuccessfact ors/ diakses tgl 20 Mei 2012)

Mulyadi, (2007), Sistem Perencanaan dan Pengendalian Manajemen, Salemba Empat, Jakarta.

Niven, Paul R., (2002), Balanced Scorecard Step by Step : Maximizing Performance and Maintaining Results, John Wiley \& Sons, Inc., New York.

Parmenter, David (2010). Developing, Implementing, and Using Winning KPIs, Wiley \& Sons, Inc., New York.

Rampersad, Hubert K. (2005), Total Performance Scorecard, PT Gramedia Pusaka Utama, Jakarta.

Ward, John and Peppard, Joe, (2003), Strategic Planning for Information Systems, 3rd Edition, John Wiley \& Son's Ltd. Cranfield, Bedfordshire, UK.

Wibisono, Eric (2010). Balanced Scorecard, Malcolm Baldrige National Quality Award \& Performance Prism: Tinjauan Evolusi Dua Dekade Sistem Pengukuran Kinerja, Prosiding Seminar Nasional Teknoin 2010, Yogyakarta.

Widjaja T, Amin, (2002), Memahami Konsep Balanced Scorecard, Harvarindo, Jakarta.

Widjaja T, Amin, (2003), Pengukuran Kinerja dengan Balanced Scorecard, Harvarindo, Jakarta.

Yuwono, Sony, (2004), Petunjuk Praktis Penyusunan Balanced Scorecard, PT. Gramedia Pustaka Utama, Jakarta. 